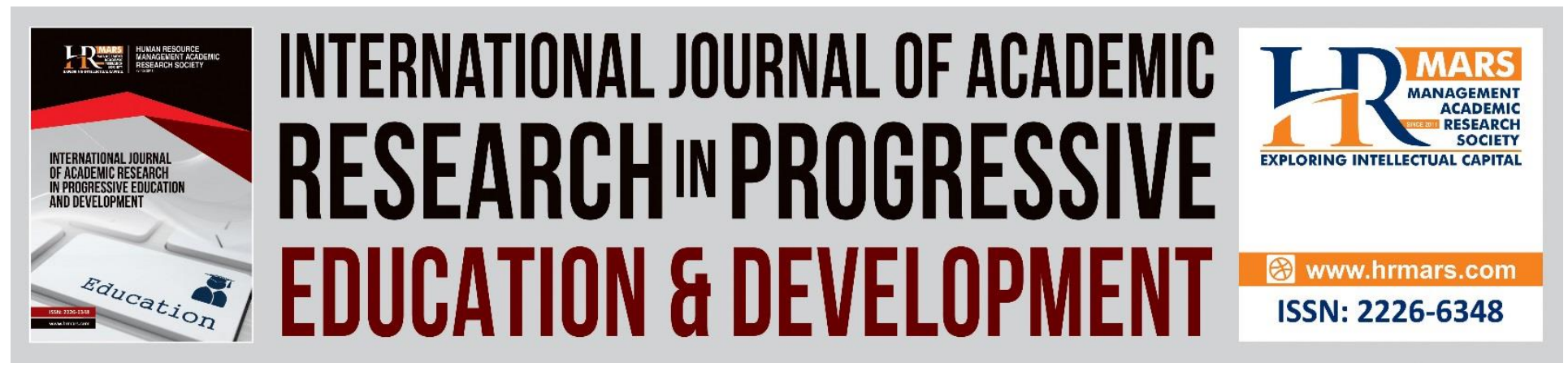

\title{
A Review on the Students' Perceptions of Online Learning Tools in Improving English Writing Skills
}

Or-Kan Soh, Lee-Ann Daniella Lim, Lo Yuok Yee, Lai Ke Ying, Lim Li Yin

To Link this Article: http://dx.doi.org/10.6007/IJARPED/v7-i4/4979

DOI: $10.6007 /$ IJARPED/v7-i4/4979

Received: 18 Oct 2018, Revised: 28 Nov 2018, Accepted: 28 Dec 2018

Published Online: 30 Dec 2018

In-Text Citation: (Soh, Lim, Yee, Ying, \& Yin, 2018)

To Cite this Article: Soh, O.-K., Lim, L.-A. D., Yee, L. Y., Ying, L. K., \& Yin, L. L. (2018). A Review on the Students' Perceptions of Online Learning Tools in Improving English Writing Skills. International Journal of Academic Research in Progressive Education and Development, 7(4), 324-348.

Copyright: (c) 2018 The Author(s)

Published by Human Resource Management Academic Research Society (www.hrmars.com)

This article is published under the Creative Commons Attribution (CC BY 4.0) license. Anyone may reproduce, distribute, translate and create derivative works of this article (for both commercial and non-commercial purposes), subject to full attribution to the original publication and authors. The full terms of this license may be seen

at: http://creativecommons.org/licences/by/4.0/legalcode

Vol. 7, No. 4, 2018, Pg. 324 - 348

http://hrmars.com/index.php/pages/detail/IJARPED

JOURNAL HOMEPAGE

Full Terms \& Conditions of access and use can be found at http://hrmars.com/index.php/pages/detail/publication-ethics 


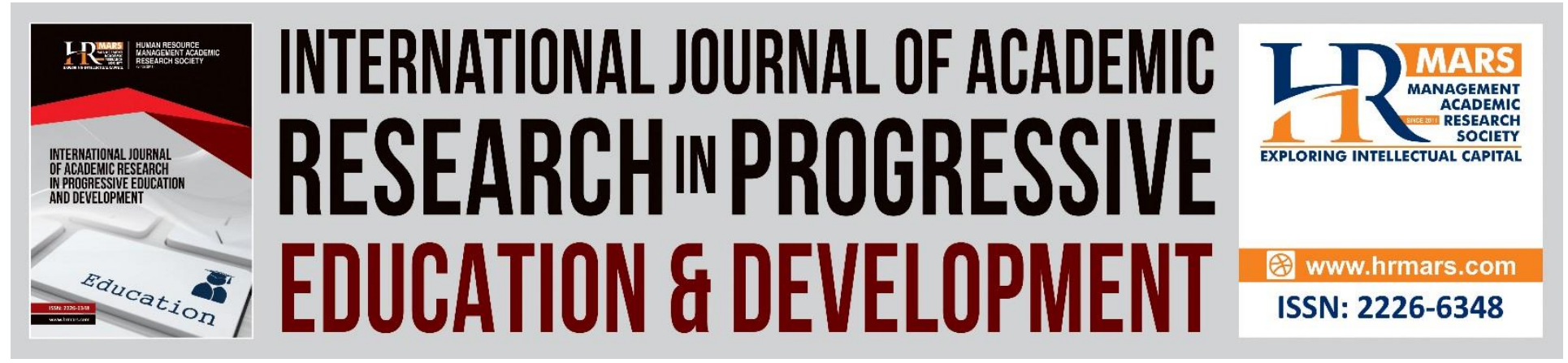

\title{
A Review on the Students' Perceptions of Online Learning Tools in Improving English Writing Skills
}

\author{
Or-Kan Soh, Lee-Ann Daniella Lim, Lo Yuok Yee, Lai Ke Ying, \\ Lim Li Yin
}

The School of Language Studies \& Linguistics, Universiti Kebangsaan Malaysia, Malaysia 43600 UKM Bangi, Selangor, Malaysia.

Email:sok@ukm.edu.my

\begin{abstract}
Online learning tools may help students in enhancing their writing skills. This study aims to figure out if online learning tools help to increase active participation in writing, encourage the mental development of students, identify students' perception towards teacher's role as facilitator and the relationship between the social context of students and their motivation in writing. One hundred and fifty-four English Language Studies students at The National University of Malaysia (UKM) participated in the study. Based on the analysis of students' written work, the findings suggest that online learning tools integrated in writing instruction resulted in greater improvements in students' writing performance. The study therefore supports the conclusion that English Language practitioners' may use online learning tools as it has the potential to promote more effective writing instruction.

Keywords: Online Learning Tools, English, Writing Skills, Student Perceptions, Review, Improving

Abstract

Online learning tools may help students in enhancing their writing skills. This study aims to figure out if online learning tools help to increase active participation in writing, encourage the mental development of students, identify students' perception towards teacher's role as facilitator and the relationship between the social context of students and their motivation in writing. One hundred and fifty-four English Language Studies students at The National University of Malaysia (UKM) participated in the study. Based on the analysis of students' written work, the findings suggest that online learning tools integrated in writing instruction resulted in greater improvements in students' writing performance. The study therefore supports the conclusion that English Language practitioners' may use online learning tools as it has the potential to promote more effective writing instruction.
\end{abstract}




\section{Introduction}

Online learning tools are a technologically dependent means for delivering educational content to a wider audience as compared to traditional classroom environments. Blogging resources and educational apps are examples of online learning tools that offer interactive platforms for English language acquisition. The innovative technology not only incorporates an interactive environment that sustains student participation, but also encourages learners to adopt a variety of writing strategies through literacy development exercises. The potential gains for the use of blogging and educational games for improving writing skills thereby necessitate an improvement in the knowledge base regarding the use of these online learning tools.

The development of online learning tools is the result of a need for learning structures that were not confined by physical barriers such as geographical elements. In the modern context, Richardson (2003) defines online learning structures as classes that offer at least one section of the curriculum through virtual platforms. However, there is also a need for these online environments to act as a delivery platform for curriculum content while accommodating for the lack of the educator's personal presence in line with Vygotsky's sociocultural theory on the role of social interaction in writing activities. Therefore, effective online learning tools for writing development are classified as those that include discussion boards and brainstorming platforms, whereby students can interact with each other and with the teacher (Boling, 2008; Knobe \& Lankshear, 2007; Penrod, 2007).

Generally, the writing process involves adopting deliberate strategies to improve literacy development (Anderson, 2009). According to Son (2014), the social element of cognitive development stimulates reading and writing skills and is thereby essential in the improvement of writing skills. Here, reader's communication with others through verbal or written means offers opportunities for analysing the curriculum content. Therefore, the writing strategies developed and utilised in traditional learning environments should also transfer to online learning tools to ensure comparable improvements for learners (Haynes \& Zacarian, 2010).

An analysis of the existing knowledge base reveals that extant scholarly literature centres on the relevance of online learning tools for secondary and college levels (Boling, 2008; Williams \& Jacobs, 2004). Son (2014) found that online learning tools can be about any topic and can include visual aids to engage the students in vocabulary enhancement exercises. Moreover, elaborate online learning tools have been found to ensure that a variety of resources on writing strategies are provided through links to library resources and websites (Pahl \& Rowsell, 2005). Essentially, students should have unlimited access to reading and writing content, meaning that online learning platforms should be compatible with all the class material formats.

The National Commission on writing (2006) encourages researchers to use online learning tools in writing skills because they reduce the amount of time students spend in writing, encourage out-of-school writing, and improve collaboration among students. Kayallis and Natsina (2010) also argue that online learning tools utilise digital resources that facilitate feedback on each student's progress to offer customised learning mechanisms depending on 
Vol. 7, No. 4, 2018, E-ISSN: 2226-6348 @ 2018 HRMARS

individual learner characteristics. Considering that each student may have a unique language learning process, Williams (2003) notes that the use of online platforms thereby ensures that each one can adopt a suitable learning speed while also promoting critical thinking in writing activities. Ultimately, online learning tools are potentially powerful collaborative tools that can be applied in cross-curricular activities while also delivering targeted learner content (Adams \& Brindley, 2007).

The analysis of extant knowledge reveals a gap in the literature regarding the ways through which online learning tools improve the writing of undergraduate students. Considering the contributions that these existing scholarly activities have made to the field, it is thereby essential to analyse the utility of these online learning tools in the development of undergraduate writing skills. This will be essential in enhancing the understandings that scholars and educators have regarding the potential benefits and shortcomings of using online learning tools for writing skills as well as for cross-curricular activities in the online space.

\section{Research Questions}

This study intends to examine the way collaborative online learning tools help undergraduate ESL students improve their English writing skills. The study is guided by the following research questions:

- "Participation"- How do online learning tools create interactions with real audiences?

- "Mental development"- How important is mental development on writing skills with the use of online learning tools?

- "Facilitation"- What do students think of the teacher's role as facilitator in the learning tools?

- "Social Context"- What extent does social context effect writing skills through online learning tools?

\section{Literature Review}

\section{The effects of using Blogs on students' writing skills}

Previous studies have demonstrated a positive impact on supporting students' learning processes and outcomes (Waycott \& Kennedy, 2009; McLoughlin \& Lee, 2008) by the implementation of blogging. Students were relieved of apprehension when writing on blogs compared to those who wrote with pen and paper. Students were more willing to share with readers about their passion, interests and opinions on various topics and thus it helped to enhance students' confidence. Moreover, students' writing attitudes and affections toward writing were improved in this collaborative writing process, which strengthened their writing competence and increased their motivation. Hence, students as bloggers were willing to take risks and to explore new subject areas in their writing.

Students developed their confidence in writing and established their own personal writing styles (Murray \& Hourigan, 2006), whilst at the same time experiencing the disclosure of their own self and personal growth when reflecting on their postings (Oravec, 2002; Wagner, 2003). Furthermore, students were able to write freely, this promoted self-expression, self-reflection and construction of knowledge collaboratively. Research has indicated that student self- 

DEVELOPMENT

Vol. 7, No. 4, 2018, E-ISSN: 2226-6348 ๑ 2018 HRMARS

disclosure plays an important role in the learning experience and producing positive learning outcomes. Thus, the feedback generated from the collaborative blogging experience helped to increase students' motivation to write. Additionally, the usage of blogs enabled students to demonstrate their metacognitive knowledge by sharing how they planned and thought about the learning process and how they monitored and evaluated their production and comprehension. Students were able to develop an increased awareness of their audience, which encouraged them to critically consider how their readers might meditate on their viewpoints (Williams \& Jacobs, 2004).

\section{Students' Participation}

Blogs are used broadly in education due because it provides a real audience for student writing, provides extra reading practice for students, increases the sense of community in a class, encourages students to participate and creates an online portfolio of student written work (Stanley, 2005). Blogging can combine solitary reflection and social interaction such as interaction between peer-to-peer and teacher-student to initiate students into academic research and develop their research capabilities with a collaborative dimension. Results have highlighted that using online peer assessment can be effective for promoting students' performance and learning satisfaction and processes (Lu \& Bol, 2007; Van Gennip, Segers \& Tillema, 2010; Xie, Ke \& Sharma, 2008; Xiao \& Lucking, 2008; Chang \& Chen, 2009; Van Gennip, Segers \& Tillema, 2009; Liang \& Tsai, 2010; Van Zundert, Sluijsmans \& Van Merrienboer, 2010; Shih, 2010). Students were able to modify their original work and improve its quality (Tsai \& Tseng, 2007) in the process of reviewing and commenting on their peers' work. Students were able to self-examine, review, observe, and gain more detailed knowledge of each other's work during the peer assessment process. In addition, survey results have shown that students were able to improve their organization, grammar and structure, content, vocabulary, and spelling. Blogging makes this convenient by acting as a platform so that students are motivated to participate and enjoy the learning process. As a result, the social constructivist theory (Birch \& Volkov, 2007; Woo \& Reeves, 2007; Wilson \& Stacey, 2004; Vygotsky, 1978) shows that students with more sophisticated English writing abilities tend to have more interactions with other people and may therefore benefit more from the process of peer assessment. Students were also able to learn and improve their writing skills from those who were more knowledgeable as blogging gave them access to a broader audience. Interestingly, students' awareness of a 'real' audience with weblogs being publicly accessible encouraged them to monitor their writing. Students benefitted from blogs written by native speakers to acquire cultural knowledge from a range of different stances (Elola \& Oskoz, 2008; Pinkman, 2005). This provides genuine learning context for EFL learners who have limited opportunities to be exposed to the target language in an authentic environment. Research reveals that this increases students' interest, motivation in reading and writing, and promotes learner independence and autonomy (Pinkman, 2005; Zhang, 2009).

\section{Teacher's role as facilitator}

Students take ownership of learning to write well when they use blogs (Kim, 2008) by actively searching for information on their own. Students are given chances to learn from content that is posted online and obtain feedback provided by teachers on their blogs. Therefore, the responsibility of teachers is lessened to giving feedback and support on assignments by using 
INTERNATIONAL JOURNAL OF ACADEMIC RESEARCH IN PROGRESSIVE EDUCATION AND DEVELOPMENT

Vol. 7, No. 4, 2018, E-ISSN: 2226-6348 ๑ 2018 HRMARS

Information and Communications Technology (ICT), instead of guiding them step by step through the entire learning process of writing. Teachers need to master the use of blogs to establish effective procedures and processes to give feedback, support, and to assess student work. Hence, teacher's feedback needs to be integrated into the writing course so that the writing learning process can be implemented successfully (DiGiovanni \& Nagaswami, 2001; Liu \& Sadler, 2003; Tuzi, 2004). Vygosky (1978) stated that writing is as much as individualistic process as a social one. A teacher's guidance can help students navigate the sea of information to discover the additional wealth of knowledge within the Internet and blogging allows this in the online environment that the students are increasingly accustomed to and indeed prefer (Oblinger, 2006). On the disciplinary front, teachers can help students to develop the sufficient domainspecific knowledge and research skills or methodologies before or as they embark on their blogbased research journeys.

\section{Social context influences students' writing skills}

Blogs allow students to scaffold each other in navigating their writing tasks and processing academic writing knowledge, as well as negotiating and understanding their identities as academic writers. As the constructivist perspective proposes that effective learning involves the active process of linking learners' existing knowledge with new ideas for them to make sense of a new situation (Naylor \& Keogh, 1999), the range of different writing-related topics the students in this study discussed, shared and explored on their blogs also helped them come to a newer understanding of their experiences, performances and roles in writing. The social constructivist theory further proves that the development of knowledge requires active engagement and social interaction on the part of the learners (Jenkins, 2000). The social process serves as a means of internalizing ideas encountered in the socio-cultural realm (Nyikos \& Hashimoto, 1997). Blogs also provided a realm for students to process and reconstruct knowledge through social interaction. Thus, when one verbalized an issue or a problem via his or her blog not only reflects and responds to the issue through the process of constructing the text but also invites others to engage in the problem-solving by making the issue available for others to ponder and respond in the blog forum. Additionally, the social and emotional support revealed in the blog project indicates the potential of blogs in promoting mutually beneficial social interaction that is conducive to knowledge development.

\section{The effects of using Anytown on students' writing skills}

Some theorists in the field of education have begun to look towards the power of video games and other digital learning environments to improve student learning (Gee, 2003; Jenkins, Squire, \& Tan, 2003; Prensky, 2001; Squire \& Steinkuehler, 2005; Steinkuehler, 2004). The Anytown was designed to facilitate writing instruction as designers incorporated the use of feedback within and from the digital system, embedded scaffolds in the form of character dialogue, as well as visual and textual clue resources used to drive learning activities. Students received textual cues by clicking on objects and characters, which provided them with information about their environment and the writing process, offered positive feedback related to their progress on learning tasks when appropriate, gave additional scaffolding for learning tasks when needed, and imparted directions to learning tasks as part of the rules of their overall experience. Anytown was designed to be a self-contained unit that leveraged 3-D digital technology to establish an 
Vol. 7, No. 4, 2018, E-ISSN: 2226-6348 @ 2018 HRMARS

immersive experience for improving student writing skills. Vogel et al.'s (2006) stated that instructional computer gams seem to facilitate motivation across different learner groups and learning situations. Studies regarding games for learners typically show significant positive effects of computer games for students (e.g., Horn et al., 1991; Inal \& Cagiltay, 2007; Ota \& DuPaul, 2002 ; Padgett, Strickland, \& Coles, 2006) as a powerful instructional intervention in special education. Moreover, Anytown provided 22 possible non-required, free choice writing tasks which were Reflection, Mystery, and Creative Writing Quests. These optional learning tasks were largely intended to engage students in higher order thinking skills such as problem solving, planning, and the use of creativity in order to overcome environmental difficulties. Each task increased in difficulty and complexity over time, this allowed students to gain competency with developing appropriate writing, critical thinking, and cognitive-reflective practices (Warren et al.,2009). The need to increase student time-on-task practicing writing drove the design of the Anytown curriculum (Englert, Manalo, \& Zhao, 2004). In this development, the main elements of problembased learning (Savery \& Duffy, 1995) by including ill-structured problems that students could work to solve using the collaborative technology tools and embedded scaffolds within the digital environment. The provision of adequate hard scaffolds within the environment in the form of ingame tutors and resources (Baylor, 1999; Baylor \& Kim, 2005) help to provide increased student control over of the exploration of learning environment and their own writing products as well as improve student willingness to engage in voluntary writing practice and reading activities.

\section{Social context influences students' writing skills}

Stories can be effective at scaffolding student problem-solving in a constructivist learning environment (Jonassen \& Hernandez-Serrano, 2002). The writing practice in Anytown encompassed the use of social studies, science, health and mathematics. Students in Anytown were channelled to investigate activities that gave them opportunities for discovery, reading followed by analysis of written, mathematical and science content and connections to real world work roles which involves writing. Students' understanding of the relationship between the work they were doing in the learning environment and future career as an adult improved based on the research by Linn, Clark and Slotta (2003). In addition, the writing activities, clues and nonhuman objects in the environment included embedded hard scaffolds to help students through more difficult game and writing tasks which have been found by Brush and Saye $(2001,2003)$ and Linn et al. (2003) to be required as an aid for students when they encounter largely unstructured, open-ended activities like written response. These scaffolds were embedded in the form of character advice, instructional references on grammar, spelling, punctuation, and throughout the writing process these scaffolds acted as a guide for appropriate content and structure.

\section{Present Studies}

Using online learning tools to improve English writing skills is still new to most educational settings. Thus, most students would perceive these tools differently when used to master a particular skill. While some may agree with the benefits of using of online learning tools to improve writing skills, others that are unfamiliar with the use of online learning tools may disagree. Understanding, the perceptions of students towards online learning tools will help educational bodies consider the integration of this form of technology in their teaching courses. 
INTERNATIONAL JOURNAL OF ACADEMIC RESEARCH IN PROGRESSIVE EDUCATION AND DEVELOPMENT

Vol. 7, No. 4, 2018, E-ISSN: 2226-6348 @ 2018 HRMARS

The present study aims to find out how students perceive online learning tools in improving English writing skills.

\section{Research Methodology \\ Participants and Design}

The students who were completing their bachelor's Degree in English Language Studies were chosen for this study, the majority of the students were in their second year. Specifically, 62 of students were in their first year of university (freshman), while 68 were in their second year (sophomore), 24 students in their third year (senior). Participants' age was ranged from 19 to 23 years, both male and female students were calculated. A questionnaire was designed, constituted of 50 items, structured into two sections. The first section contained 10 demographic questions, addressing the following general data regarding the students: gender, race and class level. These ten questions were asked on an open-ended scale. For gender, the only possible answers were 'Male' or 'Female', and the other questions were asked with multiple choice answers provided.

The second section in the questionnaire was focused on students' perceptions of online learning tools which help students improve writing skills based on Vygotsky's framework. Specifically, the first part was aimed at the active participation of students in improving writing skills via online learning tools. The second part investigated the perceived effect of online learning tools towards writing skills. The third part was how students perceive teacher's role as facilitator when using online learning tools. The final part was intended to identify how the social context of students improves writing skills with online learning tools. Each of these four parts were made up of 10 items, in which students were asked about their improvements in writing skills after they experienced the use of online learning tools.

\section{Materials}

In this study the material comprised of a questionnaire which was used as a data gathering method for this study. The questionnaire consisted of an introductory section in which students indicated demographic information and the second section was divided into four other parts in which students indicated their perception towards online learning tools. Each of the four parts consisted of 10 items to which students responded using a five-point Likert-type scale (1=strongly disagree; 2=disagree; 3=neutral; 4=agree; and 5=strongly agree). Questions dealt with the improvement of writing skills on a range of variables, including frequency of using online learning tools, perceptions related to the social context of students and the perceived effect of online learning tools towards writing skills. We used previously validated scales and adapted them to the context of blogging and educational games as online learning tools that help improve English writing skills. We adapted the measurements for teacher's role as facilitator, students feedback on online learning tools, social context influencing writing skills, perception of students towards online learning tools from Mubaslat (2011), Hsu and Lin (2007), and Jimoyiannis, Tsiotakis, and Roussinos (2013).

\section{Procedures}

After confirming the content of the questionnaire, we distributed 154 questionnaires to English Language Studies students randomly. The duration of completing this questionnaire was 2 weeks. 


\section{INTERNATIONAL JOURNAL OF ACADEMIC RESEARCH IN PROGRESSIVE EDUCATION AND DEVELOPMENT}

Vol. 7, No. 4, 2018, E-ISSN: 2226-6348 @ 2018 HRMARS

The mean scores of each participant were rank-ordered and divided into high, medium, and lowlevel groups. They were collected by the researchers and placed in an envelope. The survey used both Likert-type and non-Likert type questions to evaluate the students' perception of how online learning tools improve writing skills. The professor was not involved in the distribution of the questionnaires and students were verbally informed that they were free to participate. We collected the data and entered it into the Statistical Package of Social Sciences (SPSS) version for data analysis of the information.

\section{Results}

\section{Demographic of respondents}

The findings from table 4.1.1 (in Appendix), figure 4.1.2, figure 4.1.3 and figure 4.1.4 revealed 60 (44.2\%) of the respondents were at the sophomore level, followed by 62 (40.3\%) were freshman and 24 (15.6\%) were junior. In term of gender, a large number of respondents 127 (82.5\%) were female while $27(17.5 \%)$ were male. The majority of respondents 130 (84.4\%) were Malay, followed by Chinese 10 (6.5\%), Indian 12 (7.8\%) and others 2 (1.3\%).

\section{Current Class Level}

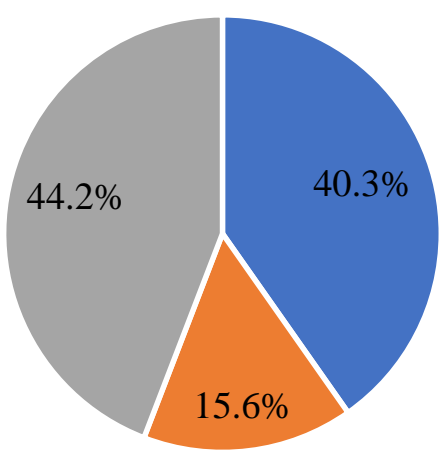

- Freshman (1st Year) $\quad$ Junior (3rd Year) $\quad$ Sophomore (2nd Year)

Figure 4.1.2: Distribution of respondents according to current class level 
INTERNATIONAL JOURNAL OF ACADEMIC RESEARCH IN PROGRESSIVE EDUCATION AND DEVELOPMENT

Vol. 7, No. 4, 2018, E-ISSN: $2226-6348$ @ 2018 HRMARS

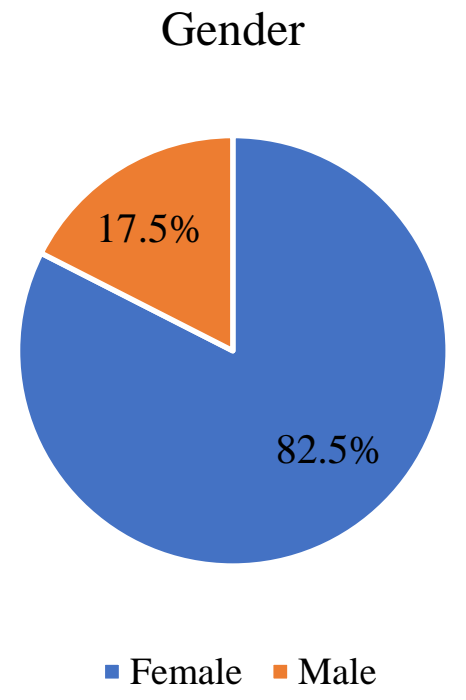

Figure 4.1.3: Distribution of respondents according to gender

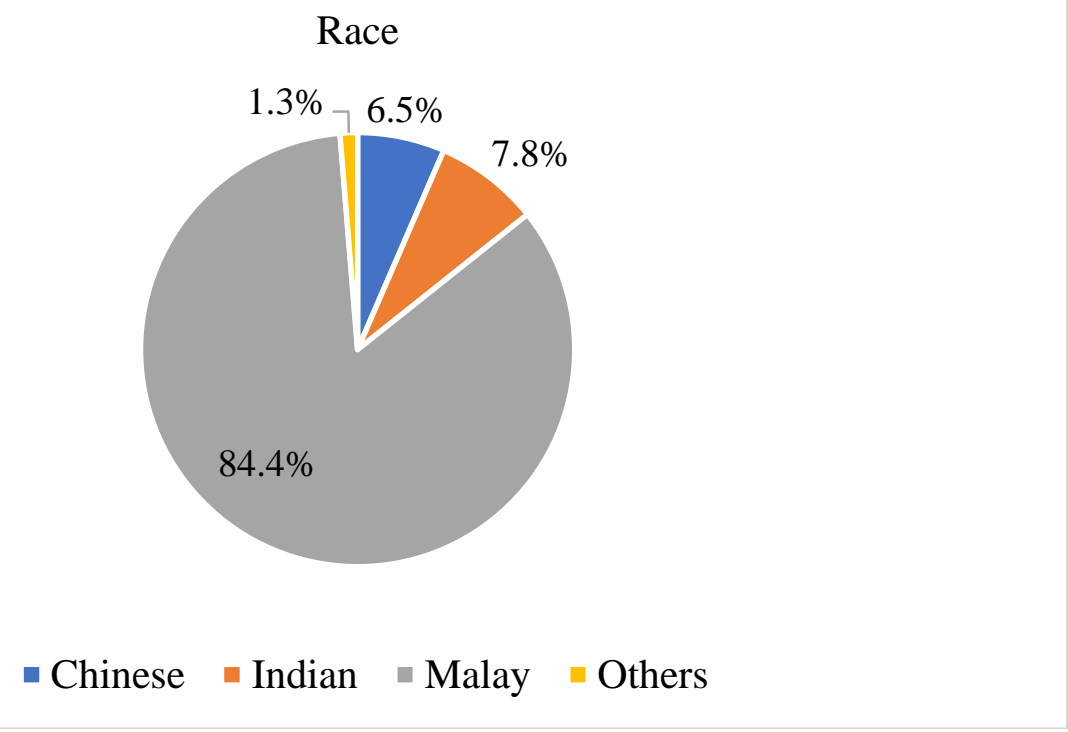

Figure 4.1.4: Distribution of respondents according to race 
INTERNATIONAL JOURNAL OF ACADEMIC RESEARCH IN PROGRESSIVE EDUCATION AND DEVELOPMENT

Vol. 7, No. 4, 2018, E-ISSN: 2226-6348 @ 2018 HRMARS

The frequency of using online learning tool

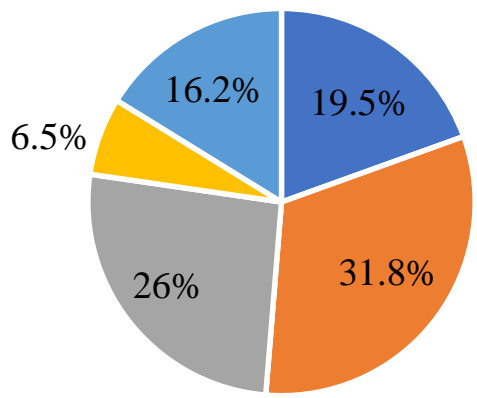

- A few times a month $\approx$ A few times a week $\square$ Daily

- Once a month $\quad$ Once a week

Figure 4.2.2: The distribution of respondents according to the frequency of using online learning tool.

How long have you been using online learning tools?

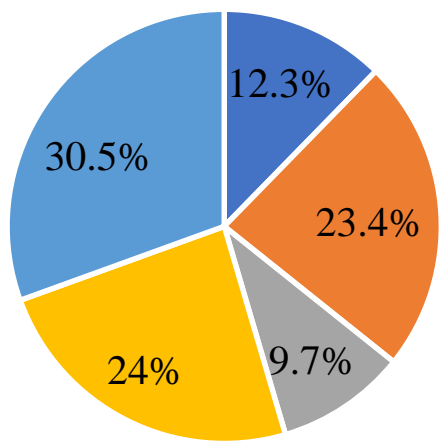

" Four years $\square$ More than four years $\square$ One year $\square$ Three years $\square$ Two years

Figure 4.2.3: The distribution of respondents according to the period of using online learning tool. 
INTERNATIONAL JOURNAL OF ACADEMIC RESEARCH IN PROGRESSIVE EDUCATION AND DEVELOPMENT

Vol. 7, No. 4, 2018, E-ISSN: $2226-6348$ @ 2018 HRMARS

How important is online learning tools for you

$\square$ Important $\square$ Less important $\square$ More important $\square$ Not important $\square$ Very important

Figure 4.2.4: The distribution of respondents according to the level of important using online learning tool.

How good do you think you are using online learning tools?

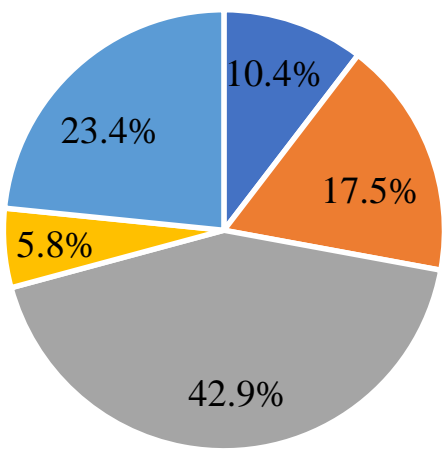

$$
\text { - Excellent } \quad \text { Fair } \quad \text { Good } \square \text { Poor } \quad \text { Very good }
$$

Figure 4.2.5: The distribution of respondents according to level of expertise using online learning tool. 
INTERNATIONAL JOURNAL OF ACADEMIC RESEARCH IN PROGRESSIVE EDUCATION AND DEVELOPMENT

Vol. 7, No. 4, 2018, E-ISSN: 2226-6348 @ 2018 HRMARS

Where do you access online learning tools?

- Home / Student Residence

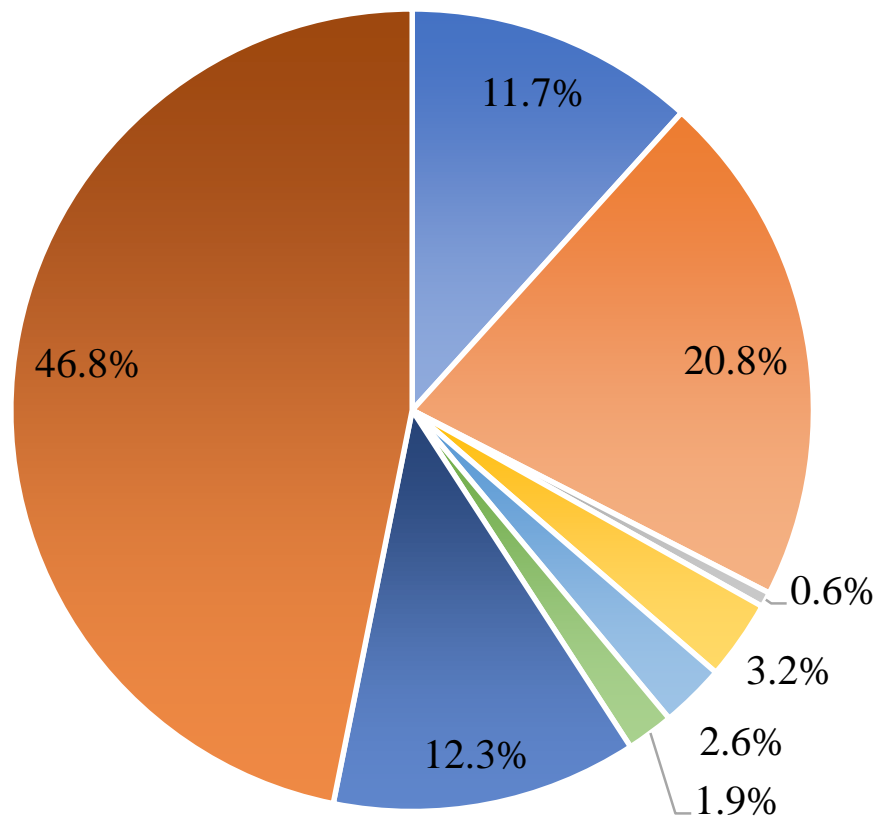

- Home / Student

Residence;University

- Home / Student

Residence;University;Other

location

- Home / Student

Residence;University;Restaurant / Cafe

- Home / Student

Residence;University;Restaurant / Cafe;Other location

- Other location

- Restaurant / Cafe

- University

Figure 4.2.6: The distribution of respondents according to location of access using online learning tool

Who encourages you to use online learning tools?

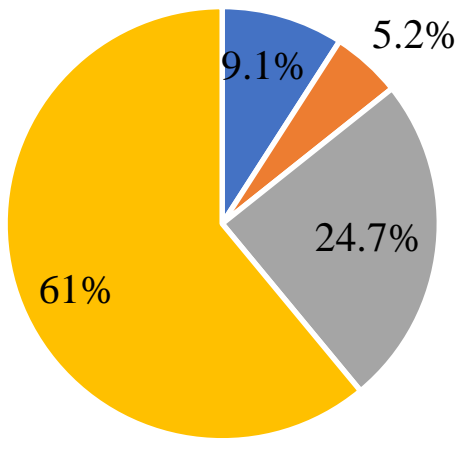

- Family - Others $\square$ Peers $\square$ Teachers

Figure 4.2.7: The distribution of respondents according to encourage online learning tool. 
Vol. 7, No. 4, 2018, E-ISSN: 2226-6348 @ 2018 HRMARS

\section{Online Learning Tool Information}

The table 4.1.2 (in Appendix) , figure 4.2.2, figure 4.2.3, figure 4.2.4, figure 4.2.5, figure 4.2 .6 and figure 4.2.7 illustrate the frequency and percentage of students that used online learning tools, 39 (31.8\%) a few times a week, followed by 40 (26\%) daily, 30 (19.5\%) a few times a month, 25 (16.2\%) once a week and 10 (6.5\%) once a month. 47 (30.5\%) had been using online learning tool for two years, followed by 37 (24\%) three years, 36 (23.4\%) more than 4 years, 19(12.3\%) four years and 15 (9.7\%) one year. Most of the respondents 66 (42.9\%) felt that online learning tools is important, followed by $34(22.1 \%)$ less important, 30 (19.5\%) very important, 9 (5.8\%) not important and 15 (9.7\%) more important. In term of skills 66 (42.9\%) were at the good level, followed by $36(23.4 \%)$ very good, $16(10.4 \%)$ excellent and $9(5.8 \%)$ were poor. The majority of respondents $72(46.8 \%)$ access online learning tool in university.94 (61\%) of the respondents encourage them to use online learning tools, followed by 38 (24.7\%) said peer, 14 (9.1\%) family and $8(5.2 \%)$ others. Majority of the students accessed online learning tools at university (46.8\%), $(20.8 \%)$ accessed online learning tools at home, student residence and university, $(12.3 \%)$ at restaurant and café, (11.7\%) home and student residence, (3.2\%) at home, student residence, university, restaurant and café, $(2.6 \%)$ at home, student residence, university, restaurant, café, other location, $(1.9 \%)$ at other locations, $(0.6 \%)$ at home, student residence, university and other location.

\section{Active Participation (\%)}

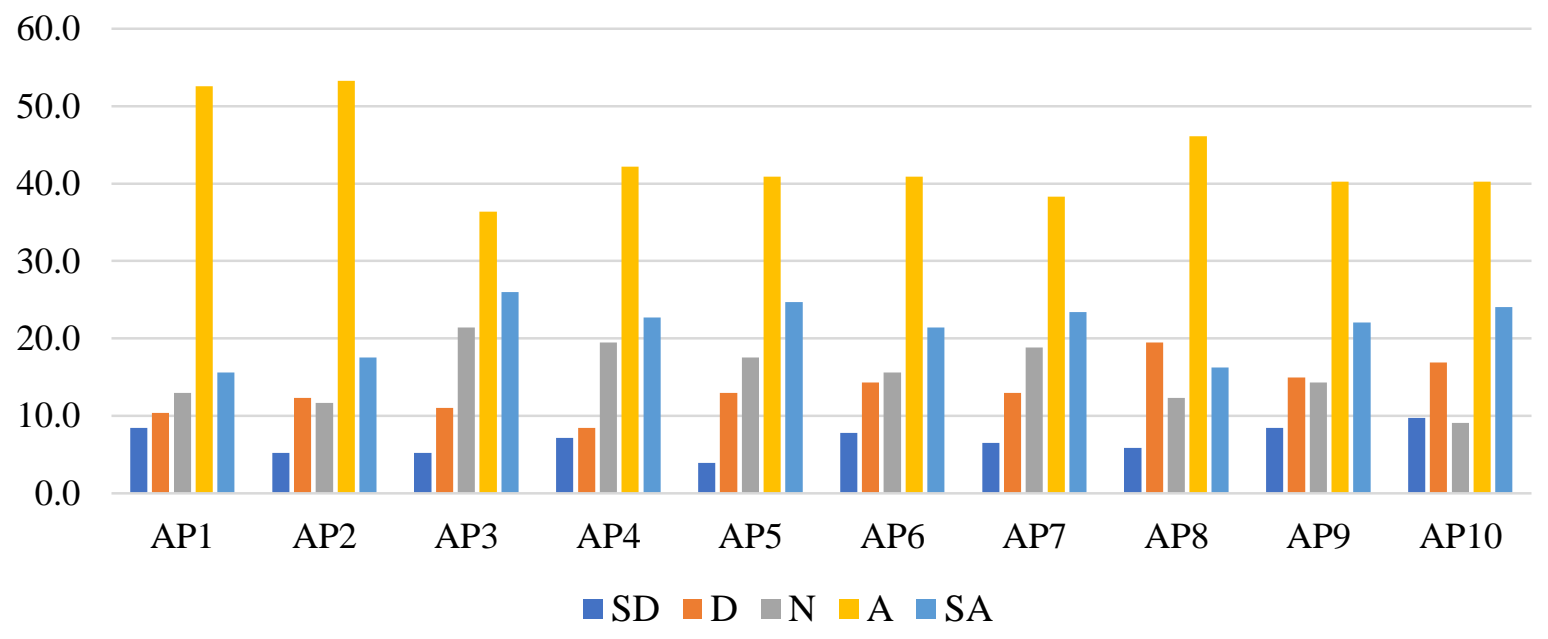

Figure 4.2.1: The distribution of respondents based on feedback toward active participation

The table 4.2.1 (in Appendix) and figure 4.2.1 shows lowest the percentage of students who strongly disagreed (8.4\%) with the statement (AP1) sharing knowledge on online learning tools would strengthen the tie between students and peers, $(10.4 \%)$ disagreed, $(13 \%)$ remained neutral, (52.6\%) agreed and (15.6\%) strongly agreed. The majority of students agreed (53.2\%) with statement (AP2) online learning tools enhanced opportunities to interact and collaborate, to share content and ideas and to construct knowledge, (17.5\%) strongly agreed, (11.7\%) remained neutral, (12.3\%) disagreed and (5.2\%) strongly disagreed. For statement (AP3) online learning tools provide students with opportunities to reflect on their experiences, posing 


\section{INTERNATIONAL JOURNAL OF ACADEMIC RESEARCH IN PROGRESSIVE EDUCATION AND}

DEVELOPMENT

Vol. 7, No. 4, 2018, E-ISSN: 2226-6348 @ 2018 HRMARS

contradictions, addressing misconceptions with their peers, (5.2\%) strongly disagreed, (11\%) disagreed, (21.4\%) remained neutral, $(36.4 \%)$ agreed, $(26 \%)$ strongly agreed. The percentage of students that remained neutral is $19.5 \%$ for statement (AP4) online learning tools can assist students through interacting with peers and enable them to read more resources online, thus improve their writing skills, (22.7\%) strongly agreed, (42.2\%) agreed, (8.4\%) disagreed, and (7.1\%) strongly disagreed. Majority of students agreed (40.9\%) and strongly agreed $(24.7 \%)$ to (AP5) students share educational and training expertise with peers by giving or receiving feedbacks, disagreed (13\%) strongly disagreed (3.9\%) and remained neutral (17.5\%). The lowest percentage of students strongly disagreed (7.8\%) with (AP6) online learning tools capture students' attention and participation between peers because they can motivate students to learn more and transform a boring class into a challenging one, (14.3\%) disagreed, remained neutral (15.6\%), agreed (40.9\%) and strongly agreed (21.4\%). For statement (AP7) online learning tools can enormously increase students' proficiency in writing skills because students have a chance to write with a purpose in the situations provided with peers, $(6.5 \%)$ strongly disagreed, (13\%) disagreed, (18.8\%) remained neutral, $(38.3 \%)$ agreed and $(23.4 \%)$ strongly agreed. The smallest percentage of students (5.8\%) strongly disagreed with (AP8) blogs create acceptance among diverse viewpoints in which students are sharing opinions and reflecting on others thought processes and create genuine opportunities for students to contribute, (19.5\%) disagreed, $(12.3 \%)$ remained neutral, $(46.1 \%)$ agreed and (16.2\%) strongly agreed. For statement (AP9) online learning tools encourage students to share their creativity in writing and developing solutions between peers, (14.3\%) remained neutral, $(40.3 \%)$ agreed, $(22.1 \%)$ strongly agreed, (14.9\%) disagreed and (8.4\%) strongly disagreed. The highest percentage of students (40.3\%) agreed with (AP10) online learning tools are strong indicators of collaborative work and interaction amongst students, (24.0\%) strongly agreed, (9.1\%)remained neutral, (16.9\%) disagreed and $(9.7 \%)$ strongly disagreed.

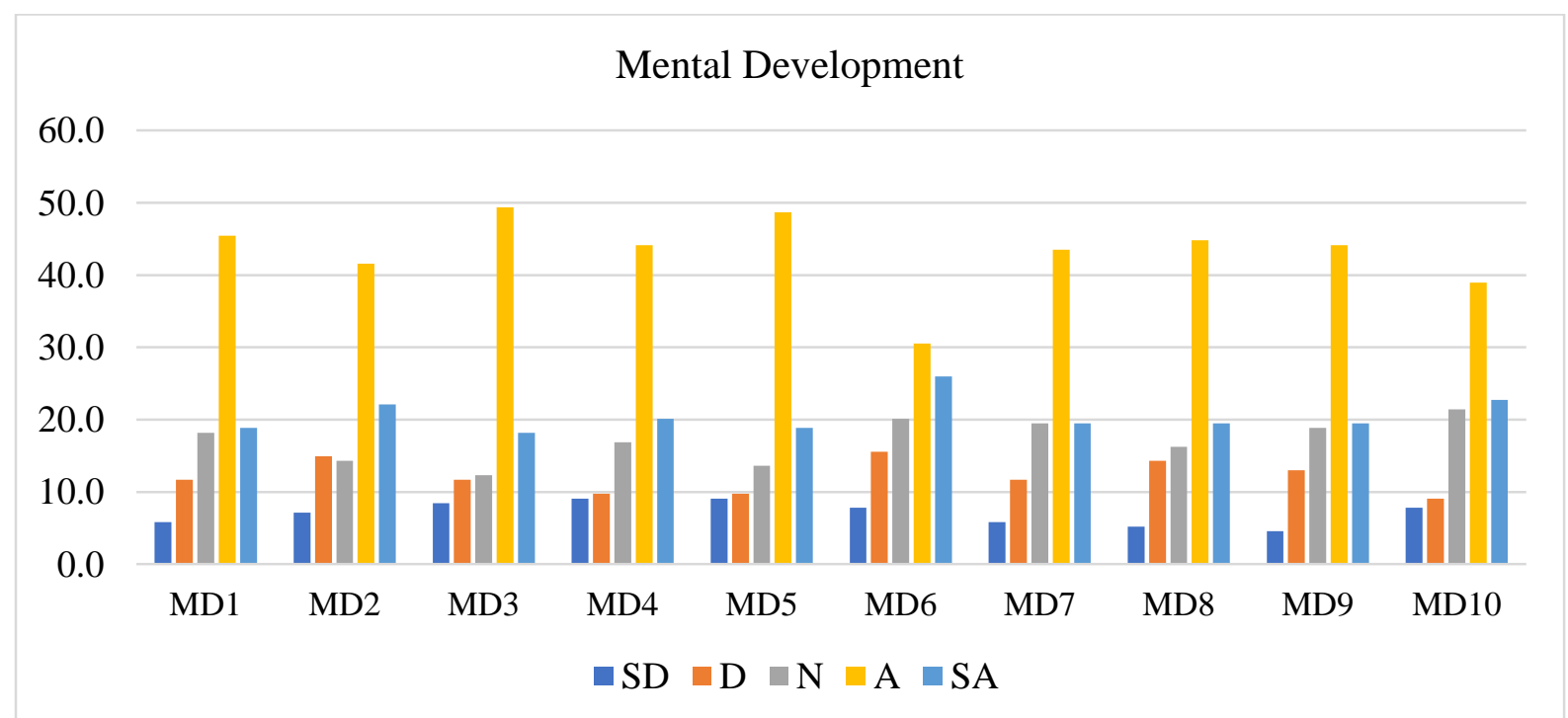

Figure 4.2.2: The distribution of respondents based on feedback toward mental development

The table 4.2.2 (in Appendix) and figure 4.2.2 shows the highest percentage of students who agreed (45.5\%) with the statement (Md1) online learning tools challenge students to apply 


\section{INTERNATIONAL JOURNAL OF ACADEMIC RESEARCH IN PROGRESSIVE EDUCATION AND}

DEVELOPMENT

Vol. 7, No. 4, 2018, E-ISSN: 2226-6348 ๑ 2018 HRMARS

the information, thus allowing them to evaluate their critical thinking skills and improve their writing skill, $(18.8 \%)$ strongly agreed, $(18.2 \%)$ remained neutral, $(11.7 \%)$ disagreed and $(5.8 \%)$ strongly disagreed. The lowest percentage of students strongly disagreed (7.1\%) with statement (Md2) online learning tools spur motivation, promote communicative competence and have a significant role in improving students' writing skills, (14.9\%) disagreed, (14.3\%) remained neutral, $(41.6 \%)$ agreed and $(22.1 \%)$ strongly agreed. For statement (Md3) students get very absorbed in the competitive aspects of online learning tools, moreover, students try harder at online learning tools than in other courses, (18.2\%) strongly agreed, $(49.4 \%)$ agreed, $(12.3 \%)$ remained neutral, (11.7\%) disagreed, (8.4\%) strongly disagreed. The percentage of students that remained neutral is $16.9 \%$ for statement (Md4) improving writing skills require a great deal of effort, online learning tools help students to make and sustain the effort of learning, (9.1\%) strongly disagreed, $(9.7 \%)$ disagreed, (44.2\%) agreed, and (20.1\% ) strongly agreed. Majority of students agreed (48.7\%) and strongly agreed (18.8\%) to (Md5) the use of innovative online learning tools can increase enthusiasm and reinforce previously presented didactic information, disagreed (9.7\%) strongly disagreed (9.1\%) and remained neutral (13.6\%). The lowest percentage of students strongly disagreed (7.8\%) with (Md6) students feeling unmotivated when the teacher restricted their free choice activity in the classroom environment that would have allowed them to complete notetaking and writing on paper, (15.6\%) disagreed, remained neutral (20.1\%), agreed (30.5\%) and strongly agreed (26\%). For statement (Md7) online learning tools validate students' efforts and increase their confidence by allow them to see their work "published" online, (19.5\%) strongly agreed, (43.5\%) agreed, (19.5\%) remained neutral, $(11.7 \%)$ disagreed and $(5.8 \%)$ strongly disagreed. The highest percentage of students (44.8\%) agreed with (Md8) online learning tools generate lower levels of anxiety and improved performance compared to pen-and-paper, (19.5\%) strongly agreed, (16.2\%) remained neutral, (14.3\%) disagreed and $(5.2 \%)$ strongly disagreed. For statement (Md9) optional learning tasks on online learning tools are largely intended to engage students in higher order thinking skills such as problem solving, planning and the use of creativity in order to overcome environmental difficulties, (18.8\%) remained neutral, (44.2\%) agreed, (19.5\%) strongly agreed, (13\%) disagreed and (4.5\%) strongly disagreed. The highest percentage of students (39\%) agreed with (Md10) motivating elements in online learning tools such as challenges and rewards increase student motivation for voluntary writing, $(22.7 \%)$ strongly agreed, (21.4\%) remained neutral, (9.1\%) disagreed and (7.8\%) strongly disagreed. 


\section{INTERNATIONAL JOURNAL OF ACADEMIC RESEARCH IN PROGRESSIVE EDUCATION AND}

DEVELOPMENT

Vol. 7, No. 4, 2018, E-ISSN: 2226-6348 @ 2018 HRMARS

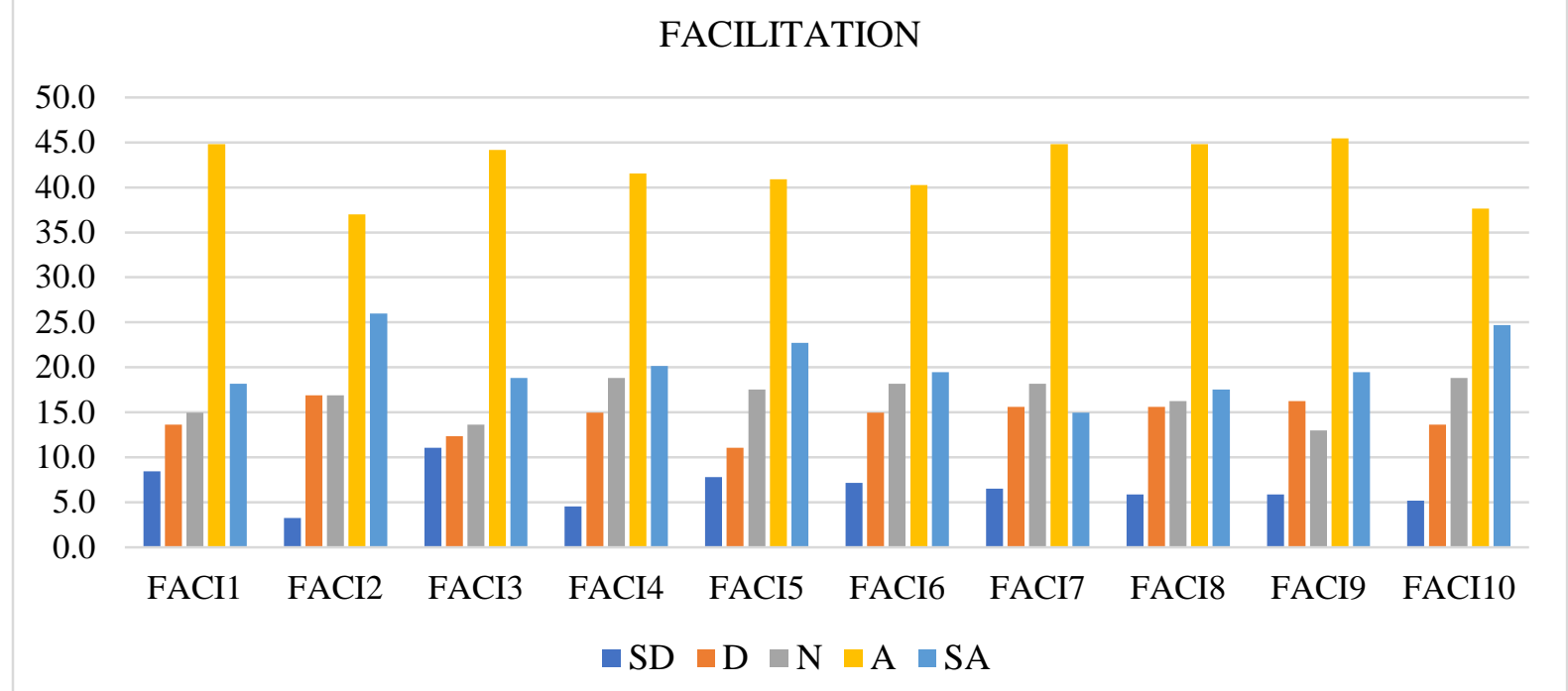

Figure 4.2.3: The distribution of respondents based on feedback toward facilitation.

The table 4.2.3 (in Appendix) and figure 4.2.3 shows lowest the percentage of students who strongly disagreed (8.4\%) with the statement (FAC1) teachers play the role of considering the advantages of online learning tools to capture students' attention, lower students' stress and give students the chance for real communication, (13.6\%) disagreed, (14.9\%) remained neutral, (44.8\%) agreed and (18.2\%) strongly agreed. The majority of students agreed (37\%) with statement (FAC2) teachers introduce students to new ideas, grammar and knowledge to improve students' writing skills via online learning tools, (26\%) strongly agreed, (16.9\%) remained neutral, (16.9\%) disagreed and (3.2\%) strongly disagreed. For statement (FAC3) teachers need to consider which elements in online learning tools are suitable to use, when to use them and how to link them up with the syllabus, text book or programmed, (11\%) strongly disagreed, (12.3\%) disagreed, (13.6\%) remained neutral , (44.2\%) agreed, (18.8\%) strongly agreed. The percentage of students that remained neutral is $18.8 \%$ for statement (FAC4) teachers create quizzes, exams and discussion pieces into a blog posting in an innovative way can improve writing skills of students, (20.1\%) strongly agreed, (41.6\%) agreed, (14.9\%) disagreed, and $(4.5 \%)$ strongly disagreed. Majority of students agreed (40.9\%) and strongly agreed (22.7\%) to (FAC5) the teacher and peer facilitator play the role of editor and provided both positive and negative feedback to student writing tasks via the educational game could improve students' writing skills, disagreed (11\%) strongly disagreed $(7.8 \%)$ and remained neutral $(17.5 \%)$. The lowest percentage of students strongly disagreed (7.1\%) with (FAC6) teachers provide as many similar social contexts as possible for learners and offer sufficient information for them to draw up the writing purposes, (14.9\%) disagreed, remained neutral (18.2\%), agreed (40.3\%) and strongly agreed (19.5\%). For statement (FAC7) teacher developed a series of voluntary writing activities that paralleled those offered in online learning tools could improve students' writing skills, (6.5\%) strongly disagreed, (15.6\%) disagreed, (18.2\%) remained neutral, $(44.8 \%)$ agreed and (14.9\%) strongly agreed. The smallest percentage of students (5.8\%) strongly disagreed with (FAC8) peer facilitators provide guidance and direction to students when they face difficulties in learning, (15.6\%) disagreed, (16.2\%) remained neutral, (44.8\%) agreed and (17.5\%) strongly agreed. For statement (FAC9) 


\section{INTERNATIONAL JOURNAL OF ACADEMIC RESEARCH IN PROGRESSIVE EDUCATION AND}

DEVELOPMENT

Vol. 7, No. 4, 2018, E-ISSN: 2226-6348 @ 2018 HRMARS

teacher develops activities that provide students with opportunities to share module relevant information via online learning tools to enhance their writing skills, (13\%) remained neutral, (45.5\%) agreed, (19.5\%) strongly agreed, (16.2\%) disagreed and (5.8\%) strongly disagreed. The highest percentage of students (37.7\%) agreed with (FAC10) teachers ensure all students can access and are supported in using the online interactive learning environment, $(24.7 \%)$ strongly agreed, (18.8\%) remained neutral, (13.6\%) disagreed and (5.2\%) strongly disagreed.

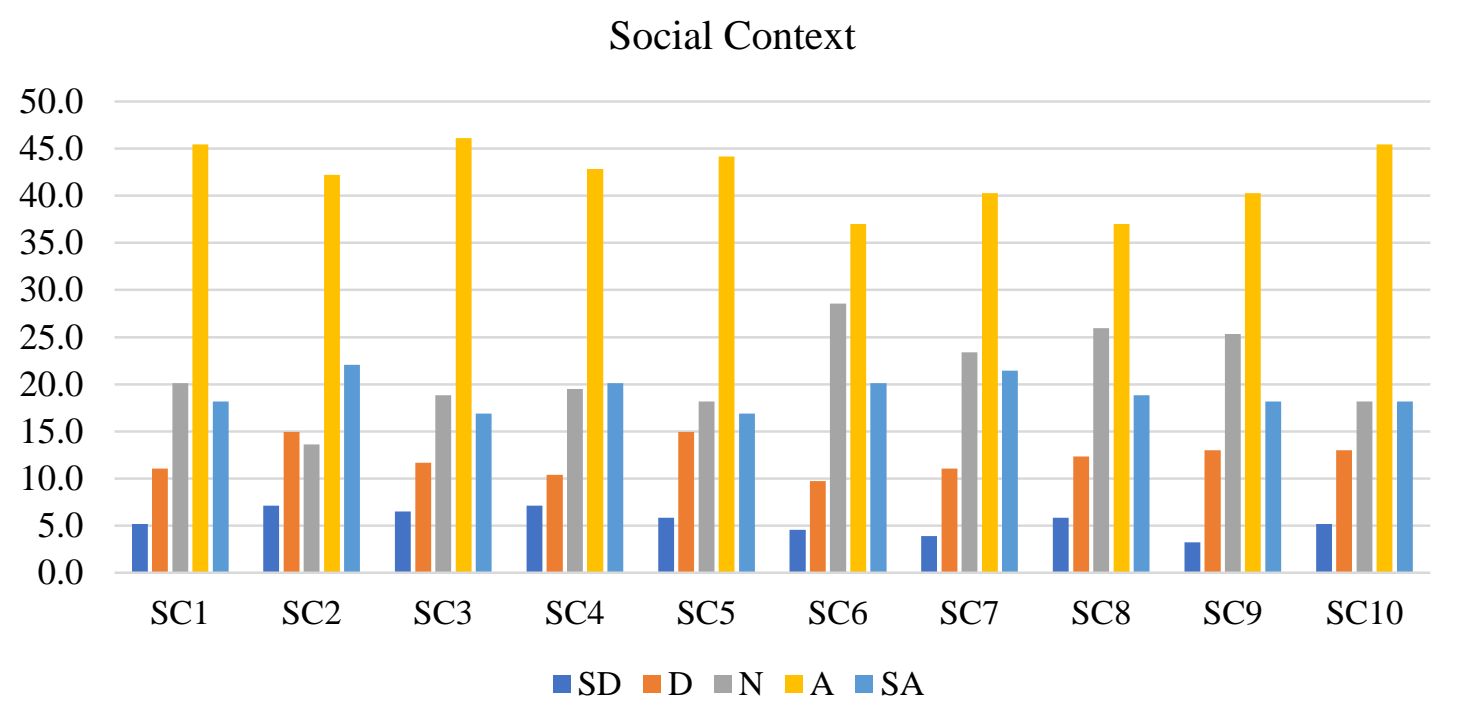

Figure 4.2.4: The distribution of respondents based on social context.

The table 4.2.4 (in Appendix) and figure 4.2.4 shows the highest percentage of students who agreed $(45.5 \%)$ with the statement (SC1) the design of online learning tools in order to set students learning in an authentic environment with which they already had some background knowledge that helps to situate the learner in a modelled space not radically different from his or her own experience, (18.2\%) strongly agreed, (20.1\%) remained neutral, $(11 \%)$ disagreed and (5.2\%) strongly disagreed. The lowest percentage of students strongly disagreed (7.1\%) with statement (SC2) online learning tools create a challenging constructively competitive atmosphere that facilitates interaction among students in a friendly and fun environment, (14.9\%) disagreed, (13.6\%) remained neutral, (42.2\%) agreed and (22.1\%) strongly agreed. For statement (SC3) if students engaged in a form of experiential learning in a place where they are educated via online learning tools, the details of the events, places and people would remain more firmly in their minds and then would transfer to more vivid and detailed descriptive writing, $(16.9 \%)$ strongly agreed, (46.1\%) agreed, (18.8\% ) remained neutral , (11.7\%) disagreed, (6.5\%) strongly disagreed. The percentage of students that remained neutral is $16.9 \%$ for statement (SC4) online learning tools encourage students to help each other and keen to answer their peers' questions very quickly, (7.1\%) strongly disagreed, (10.4\%) disagreed, $(42.9 \%)$ agreed, and $(20.1 \%)$ strongly agreed. Majority of students agreed (44.2\%) and strongly agreed (16.9\%) to (SC5) good writing skills occurs in sociocultural organized activities on online learning tools in which students are active in learning and managing social peers and structuring situations with access to observe and participate in culturally-valued skills and perspectives, disagreed (14.9\%) strongly disagreed (5.8\%) and remained neutral (18.2\%). The lowest percentage of students strongly disagreed (4.5\%) with (SC6) the social environment of online learning tools sends clear messages about 
Vol. 7, No. 4, 2018, E-ISSN: 2226-6348 @ 2018 HRMARS

what are important and proper ways of learning and thus improve their writing skills, (9.7\%) disagreed, remained neutral (28.6\%), agreed (37\%) and strongly agreed (20.1\%). For statement (SC7) the teacher provides an active audience for the student writer by confirming her or his understanding of the text and then by asking clarifying questions to enhance student's writing skills, (21.4\%) strongly agreed, (40.3\%) agreed, $(23.4 \%)$ remained neutral, $(11 \%)$ disagreed and (3.9\%) strongly disagreed. The highest percentage of students (37\%) agreed with (SC8) teacher creates occasions where conceptual conflict challenges students' alternative conceptions, students are motivated to be active participants in collaboratively improve their writing skills, (18.8\%) strongly agreed, (26\%) remained neutral, (12.3\%) disagreed and (5.8\%) strongly disagreed. For statement (SC9) online learning tools emphasize critical issues as meaningful learning, developing higher order thinking strategies and encouraging learners to link new information, (25.3\%) remained neutral, (40.3\%) agreed, (18.2\%) strongly agreed, (13\%) disagreed and (3.2\%) strongly disagreed. The highest percentage of students (45.5\%) agreed with (SC10) online learning tools can foster shared space or situational understanding between students that can help them negotiate meaning, design new knowledge and perceive multiple problem-solving perspectives,(18.2\%) strongly agreed, (18.2\%) remained neutral, (13\%) disagreed and $(5.2 \%)$ strongly disagreed.

\section{Correlation between Contexts}

$\mathrm{H} 1$ : There is a significant relationship between active participation and online learning tool.

\begin{tabular}{llcc}
\hline & & Online_Learning_Tool & Active_Participation \\
\hline Online_Learning_Tool & $\begin{array}{l}\text { Pearson } \\
\text { Correlation }\end{array}$ & 1 & $.651^{* *}$ \\
& $\begin{array}{l}\text { Sig. (2- } \\
\text { tailed) }\end{array}$ & .000 \\
& $\mathrm{~N}$ & 154 \\
Active_Participation & $\begin{array}{l}\text { Pearson } \\
\text { Correlation } \\
\end{array}$ & 1 \\
& Sig. (2- \\
tailed) & \\
& $\mathrm{N}$ & \\
\hline
\end{tabular}

**. Correlation is significant at the 0.01 level (2-tailed).

Table 4.3.1: Pearson correlation between active participation and online learning tool The results of Pearson correlation show there was a significant relationship between active participation and online learning tool $(r=0.651, p<0.05)$. Its indicated that online learning to strongly affected active participation in positive way. 
$\mathrm{H} 2$ : There is a significant relationship between mental development and online learning tool.

\begin{tabular}{llcc}
\hline & & Online_Learning_Tool & Mental_Develop \\
\hline & $\begin{array}{l}\text { Pearson } \\
\text { Correlation }\end{array}$ & 1 & $.605^{* *}$ \\
Online_Learning_Tool & $\begin{array}{l}\text { Sig. (2- } \\
\text { tailed) }\end{array}$ & 154 & .000 \\
& $\mathrm{~N}$ & 154 \\
& $\begin{array}{l}\text { Pearson } \\
\text { Correlation } \\
\text { Mental_Develop }\end{array}$ & $.605^{* *}$ & 1 \\
& $\begin{array}{l}\text { Sig. (2- } \\
\text { tailed) } \\
\mathrm{N}\end{array}$ & .000 & \\
\hline
\end{tabular}

**. Correlation is significant at the 0.01 level (2-tailed).

Table 4.3.2: Pearson correlation between mental development and online learning tool The results of Pearson correlation show there was a significant relationship between mental development and online learning tool $(r=0.605, p<0.05)$. Its indicated that online learning to strongly affected mental development in positive way.

H3: There is a significant relationship between facilitation and online learning tool.

\begin{tabular}{|c|c|c|c|}
\hline & & Online_Learning_Tool & Facilitation \\
\hline \multirow[t]{3}{*}{ Online_Learning_Tool } & $\begin{array}{l}\text { Pearson } \\
\text { Correlation }\end{array}$ & 1 & $.562^{* *}$ \\
\hline & $\begin{array}{l}\text { Sig. } \\
\text { tailed) }\end{array}$ & & .000 \\
\hline & $\mathrm{N}$ & 154 & 154 \\
\hline \multirow[t]{3}{*}{ Facilitation } & $\begin{array}{l}\text { Pearson } \\
\text { Correlation }\end{array}$ & $.562^{* *}$ & 1 \\
\hline & $\begin{array}{l}\text { Sig. } \\
\text { tailed) }\end{array}$ & .000 & \\
\hline & $\mathrm{N}$ & 154 & 154 \\
\hline
\end{tabular}

**. Correlation is significant at the 0.01 level (2-tailed).

Table 4.3.3: Pearson correlation between facilitation and online learning tool The results of Pearson correlation show there was a significant relationship between facilitation and online learning tool $(r=0.562, p<0.05)$. Its indicated that online learning tool strongly affected facilitation in positive way. 
H4: There is a significant relationship between social context and online learning tool

\begin{tabular}{llll}
\hline & & Online_Learning_Tool & Social_Context \\
\hline & $\begin{array}{l}\text { Pearson } \\
\text { Correlation }\end{array}$ & 1 & $.545^{* *}$ \\
Online_Learning_Tool & $\begin{array}{l}\text { Sig. } \\
\text { tailed) }\end{array}$ & $(2-$ & .000 \\
& $\mathrm{~N}$ & 154 & 154 \\
& $\begin{array}{l}\text { Pearson } \\
\text { Correlation } \\
\text { Social_Context }\end{array}$ & $.545^{* *}$ & 1 \\
& Sig. (2- \\
tailed) & .000 & \\
& $\mathrm{~N}$ & 154 & 154 \\
\hline
\end{tabular}

**. Correlation is significant at the 0.01 level (2-tailed).

Table 4.3.4: Pearson correlation between social context and online learning tool The results of Pearson correlation show there was a significant relationship between social context and online learning tool $(r=0.545, p<0.05)$. Its indicated that online learning tool strongly social context in positive way.

\section{Discussion and Limitations}

The main goal of this study was to investigate how students perceive online learning tools such as blogging and educational video game 'Anytown' improve writing skills by creating interactions with real audiences, student's perception towards the teacher's role as facilitator, the extent social context effects writing skills and the importance of online learning tools in mental development.

The questionnaire results revealed that majority of the students agreed that online learning tools increased active participation amongst students as it provided a platform for students to collaboratively work on writing tasks, share experiences and ideas, give opinions and receive feedback, while simultaneously capturing the attention of students. This finding supports the studies of Lu \& Bol (2007); Van Gennip, Segers and Tillema (2010); Xie, Ke and Sharma (2008); Xiao and Lucking (2008); Chang and Chen (2009); Van Gennip, Segers and Tillema (2009); Liang and Tsai (2010); Van Zundert, Sluijsmans and Van Merrienboer (2010); and Shih (2010) who found that working collaboratively can promote student's performance and learning satisfaction.

The findings also suggest that active participation amongst students in an online learning environment, produces a stronger bond, this supports Stanley (2005) who found that blogging created a sense of community in a class, encouraged students to participate and created an online portfolio of student's written work. Similarly, Linn, Clark, \& Slotta (2003), Samsonov, Pedersen and Hill (2006), and Squire et al. (2005) found that students who were successful at completing video game objectives tended to work and share their experiences with others this enabled them to complete the video game and move on to the next level at a faster rate. However, there could be instances where students may be reluctant to participate or interact 
INTERNATIONAL JOURNAL OF ACADEMIC RESEARCH IN PROGRESSIVE EDUCATION AND DEVELOPMENT

Vol. 7, No. 4, 2018, E-ISSN: 2226-6348 ๑ 2018 HRMARS

with their peers online where everyone can see their work. In this case, students who are shy or insecure with their current writing abilities may feel discouraged to use online learning tools.

Additionally, the results show that online learning tools improves the mental development of students, as most students agreed because it encouraged critical thinking, spurred motivation and increased their writing competence, provided competitive aspects that encouraged students to work harder, validated their effort, increased validation and confidence, provided motivating elements that rewarded students efforts, generated lower levels of anxiety, increased higher order thinking skills and creativity. Thus, there was a positive correlation between the use of online learning tools and mental development of students.

Our results further proved the studies of William and Jacobs (2004) who noted that blogging encouraged critical thinking, Murray and Hourigan (2006) who highlighted that blogging increased their confidence and established their own personal writing styles, Waycott and Kennedy (2009) who found that it relieved apprehension and Wagner (2003) who realized that by sharing on how they planned and thought about the learning process and how they monitored and evaluated their production and comprehension, improved their metacognitive knowledge. Our results agree with the claims of Vogel et al.'s (2006) who stated that video games can increase motivation regardless of the kind of learning environment or people one is learning with, and Wagner et al. (2009) who discovered that increased complexity of writing tasks within video games eventually led to increased meta-cognitive reflexes in writing. More research with regard to the ways students gain the ability to structure, analyze and synthesize information should be studied to support this finding.

Furthermore, the highest percentage of students positively perceived or seemed to agree with the role of teacher's as facilitators when using online learning tools throughout the entire learning process of improving writing skills. Teachers acting as facilitators meant that they provided a platform for real communication, introduced ideas, grammar and knowledge, considered ways to connect online learning tools with syllabus, text book or programme, created innovative online activities such as quizzes, discussion and tests, provide guidance, direction, feedback and sources of information by masquerading as digital or animated characters in an online environment, provide a social context similar to students in writing tasks, develop voluntary writing activities using online learning tools, and ensure all students had easy access to these online learning tools. This scenario is a contrast to the boring traditional classroom learning where the teacher simply spoon feeds and provides all the information and correction straight away to help students complete writing tasks, whereas online learning tools gives students the freedom to explore and learn collaboratively with their peers as the teacher merely guides the learning process instead of heavily shouldering the burden of ensuring students master appropriate writing skills.

Our results confirm the studies of DiGiovanni and Nagaswami (2001); Liu and Sadler, (2003); and Tuzi, (2004) who claimed that, teachers needed to maximise the use of ICT, to develop effective procedures and processes to give feedback, support, and to assess student work. Thus, blogging is an online environment that enables teachers to guide and navigate students through the overabundance of information present on the Internet and outside the Internet. On the other hand, with educational video games Baylor and Kim (2005) and Warren (2006) suggest the incorporation of pedagogical agents in the gaming environment to provide tools and resources 


\section{INTERNATIONAL JOURNAL OF ACADEMIC RESEARCH IN PROGRESSIVE EDUCATION AND}

DEVELOPMENT

Vol. 7, No. 4, 2018, E-ISSN: 2226-6348 @ 2018 HRMARS

so students can become better writers. However, it is should be taken into consideration that not all students would gladly embrace new changes such as teachers acting as guides instead of helping them and giving them what they want and need every step of the way in completing the task as they may be more comfortable with the traditional existing that teachers play. Further research should delve into comparing the workload should teachers decide to incorporate online learning tools or not into their lessons, in order to draw more definitive conclusions.

Teachers who tailor the written tasks or writing skills programme to the social context of students encourage students to further improve their writing skills. Our results show a positive correlation between social context and the use of online learning tools which seems to suggest that the social context of students should be taken into account as it effects their perception towards writing when using online learning tools. Majority of the students in our study agreed that social context was important to take into consideration as it encouraged students to write because it included the use of their background knowledge, facilitated interaction amongst students, students were more likely to retain and describe information related to their social context, enabled students to help each other, sociocultural activities encouraged good writing skills, brought to remembrance things that are important, encouraged understanding and engages students during lessons, challenged alternative conceptions of what they already knew, encouraged linking of new information and helped negotiate new meaning, and perceive multiple problem-solving perspectives.

This seems to align with Naylor and Keogh (1999) who found that connecting student's existing knowledge with new ideas helped them understand the topic of their writing tasks better. Similarly, Jenkins (2000) found that blogging helped students construct new knowledge in the socio-cultural realm because it enabled active social interaction. Educational video games like 'Anytown' were designed to take into account issues such as their future careers that they might be interested in as part of their writing tasks (Linn, Clark and Slotta, 2003). Increased research efforts should be carried out to find how social context encourages or limits student's effort in writing effectively using online learning tools, to conclude the level of importance it carries in improving writing skills.

\section{Conclusion and suggestions for Future Research}

As technology becomes an increasingly integral part of language education today, this paper has described the use of online learning tools among English Language Studies students in The National University of Malaysia (UKM). The findings of the study also suggest that online learning tools can be used in writing instruction, as human-computer interaction is an inevitable reality, it should be judiciously incorporated into our pedagogic decisions. The results have demonstrated that students who used the online learning tools in their writing courses outperformed those who received only in-class writing instruction in such specific areas of writing such as content as online learning tools promoted higher-order thinking skills.

The results of the present study recorded that student's writing skills can be enhanced because online learning tools can assist students through interacting with peers and enable them to read more resources online. Findings also indicate that students who are active in learning and managing social interactions with peers and structuring situations with access to observe and participate in culturally-valued perspectives. One outcome has illustrated that online learning tools help students to make and sustain the effort of learning. One immediate result in facilitation 
Vol. 7, No. 4, 2018, E-ISSN: 2226-6348 ๑ 2018 HRMARS

was that the teacher develops activities that provide students with opportunities to share module relevant information via online learning tools to enhance their writing skills.

Another issue that needs further research is how online self-evaluation is supported by online learning tools. Online self-evaluation plays the most powerful predicative role in learners' English language self-efficacy. In a further study, the online language learning systems need to be developed and technological innovations have to be employed in order to provide the access for students to receive constant and timely evaluative feedback on their learning process. Thus, students can know the evaluation of their learning process immediately after they finish using online learning tools in writing while waiting for feedback from peers and teachers. This might provide students with encouragement and develop positive self-esteem, thereby enhancing independent learning, that is, "the ability to take charge of one's learning" (Holec, 1981, p. 3). Furthermore, students with strong self-regulatory abilities in environment structuring tend to possess higher confidence in speaking and writing self-efficacy. Thus, it serves as a reminder for teachers of the necessity of training learners to acquire adequate environmental self-regulatory skills for online learning.

\section{References}

Adams, A., \& Brindley, S. (2007). Teaching secondary English with ICT. Maidenhead, England: Open University Press.

Arslan, R.S. \& Sahin-Kizil, A. (2010). How can the use of blog software facilitate the writing process of English Language learners? Computer Assisted Language Learning.

Volume 23. Issue 23. Taylor and Francis.

Fengfeng Ke. (2009). A Qualitative Meta-Analysis of Computer Games as Learning Tools. University of New Mexico, USA.

Ferdig, R.E. (2008). Handbook of Research on Effective Electronic Gaming in Education. IGI Global.

Haynes, J., \& Zacarian, D. (2010). Teaching English language learners across the content areas. Alexandria, Va: ASCD.

Kayalis, T., \& Natsina, A. (2010). Teaching literature at a distance: Open, online and blended learning. London: Continuum International Pub. Group.

Mardsen, N. \& Piggot-Irvine, E.(2012). Using blogging and laptop computers to improve writing skills on a vocational training course. Australasian Journal of Educational Technology, 28(1), Page 30-47. UNITEC New Zealand.

McBride, R. \& King, V. (2010). Improving Writing Skills Using Blogging in the Elementary Classroom: Choosing Tools They Use. In D. Gibson \& B. Dodge (Eds.), Proceedings of SITE 2010--Society for Information Technology \& Teacher Education International Conference (pp. 2768-2774). San Diego, CA, USA: Association for the Advancement of Computing in Education (AACE).

Mcgrail, E \& Davis, A .(2011). The Influence of Classroom Blogging on Elementary Student Writing. Journal of Research in Childhood Education.

Volume 25. Issue 4. Taylor and Francis.

Son, J.-B. (2014). Computer-Assisted Language Learning: Learners, Teachers and Tools. Newcastle upon Tyne: Cambridge Scholars Publishing.

Sun,Y.C., Chang,Y. (2012). Blogging To Learn : Becoming EFL Academic Writers Through 
INTERNATIONAL JOURNAL OF ACADEMIC RESEARCH IN PROGRESSIVE EDUCATION AND DEVELOPMENT

Vol. 7, No. 4, 2018, E-ISSN: 2226-6348 @ 2018 HRMARS

Collaborative Dialogues. Language Learning and Technology, Volume 16, Number 1 pp. 43-61.

Vurdien, R (2013). Enhancing Writing Skills Through Blogging In An Advanced English as a Foreign Language class in Spain. Computer Assisted Language Learning, 26:2, 126-143, doi: 10.1080/09588221.2011.639784

Warren S.J., Stein, R.A., Dondlinger M.J., Barab S.A., (2009). A Look Inside A MUVE Design Process: Blending Instructional Design and Game Principles To Target Writing Skills. Journal of Education Computing Research, Vol. 40(3) 295-321.Baywood Publishing Co., Inc. DOI:10.2190/EC.40.3.c

Warren S.J., Stein, R.A., Dondlinger M.J., Barab S.A, (2014). A MUVE towards PBL Writing. Journal of Research on Technology in Education, 41:1.

Publisher: Routledge 113-140, DOI: 10.1080/15391523.2008.10782525

Warren, S.J. (2010). The Impact of a Multi-user Virtual Environment on Teacher Instructional Time, Voluntary Student Writing Practice, and Student Writing Achievement. Thesis (PhD). Bloomington, Indiana University. 